\title{
Discussion on innovation system construction of new energy automobile industry in China
}

\author{
Zhiqiang $\mathrm{Xu}$ \\ Mechanical\& Electrical Department, Guangdong University of Science \& Technology \\ Dongguan, China \\ 450521404@qq.com
}

Keywords: innovation system construction; new energy; automobile industry

\begin{abstract}
During the past 40 years, especially in the past ten years, the state and local governments and enterprises have invested a lot of power and money in the development of automotive technology and improvement of production capacity. Through the introduction of technology and technology research, product quality and production level has greatly improved the product structure to make it more reasonable, the automobile industry has become an important sector industry of China's national economy. However, China automobile industry still cannot be called the industry with international competitiveness when we analyze China's automobile industry. The gap tends to emphasize the technology more backward, the art related industry backward and insufficient investment and so on. In the discussion of how to accelerate the industrial development of the automobile, it will be more focused on the introduction of foreign technology and equipment. Not only China's auto industry's international competitiveness has not been improved rapidly, but also led to the development of the automotive industry l industry into a "introduction of a backward introduction of" the strange circle. Nowadays, the automotive industry has really achieved sustained and rapid development, the realization of it really become a pillar industry in national economy and the target of real industry with international competitiveness in the shortest possible time.
\end{abstract}

\section{Introduction}

In the worldwide, the development of China's auto industry and the production of countries are inseparable, and they are closely related to the car market.

With the society growing fast, the development of energy automotive industry is also related to China's energy industry, which requires all industries to raise awareness of energy conservation and environmental protection, while the energy issue of the car line of the industry has become one of the major concerns. The exhibition can mainly be divided into three stages, from a single automotive product to a transnational corporation

Further, China's auto industry will move into a global value chain, and the emergence of China's national automobile industry and vehicle industrialization system has been more and more obvious.

The development of automobile industry is related to the formation of automobile industry value.At present, energy saving and environmental protection as the theme of new energy automotive R \& D has been made successfully.As the main way of thinking for the developed countries to seize the future automotive industry, the basic strategy of the European and American countries for the new energy automotive industry is to introduce new energy industry.

The strategic thought of the source car, realizing the environmental protection of the automobile industry through technical research. and China's new energy system is still imperfect, while compared with Europe and the United States and other developed countries.However, the progress of new energy vehicle technology and the attack on the domestic auto market in China keeps adding.

Therefore, It is urgent to set up a complete innovation system of new energy automotive industry to upgrade the competitiveness of China's new energy vehicles to develop a wider range of automotive market. 


\section{II.Innovation system construction of new energy automobile industry in China}

The following diagram briefly illustrates the construction of China's new energy automotive industry, an important part of the innovation system, the following also follow this idea.

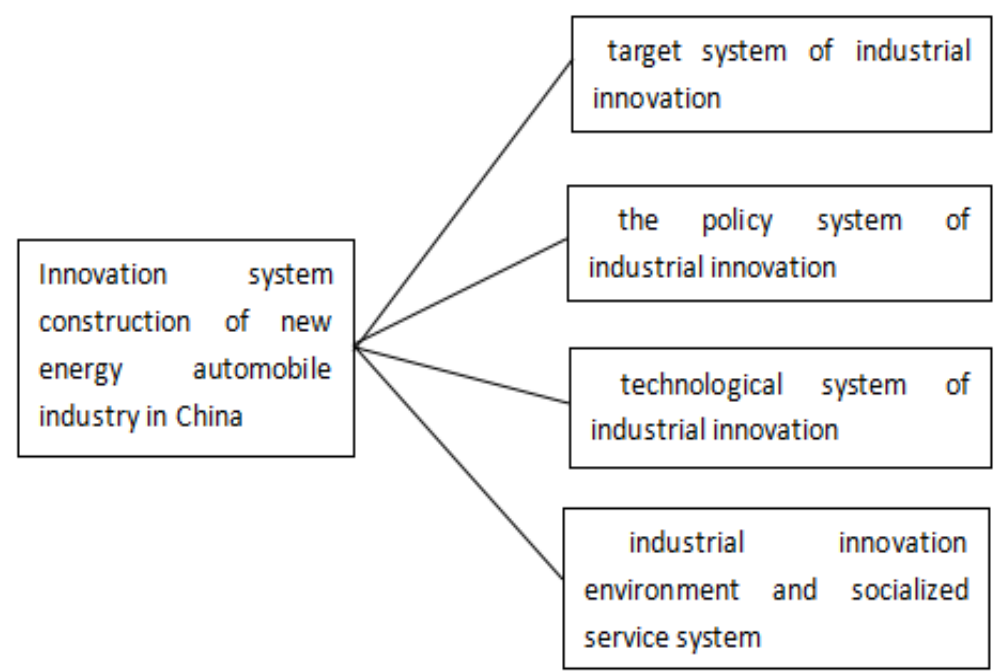

Figure 1. China's new energy automotive industry innovation system

\section{A. Target System of Industrial Innovation}

Relevant research shows that industrial innovation goals are conducive to promoting industrial performance and technological progress. As the automobile industry usually faces the international market and the industry has an international level, the innovation of the new energy vehicles is inseparable from the comparative advantages of the international market.

The basic connotation of the new energy automotive industry innovation is target system in China.Not only in the international competition and comparison, but also in the global division of labor system and the integrated module decomposition system, which shapes the competitiveness of China's new energy automotive industry.

In the process of establishing the target system of new energy vehicles, automobile manufacturers should not only consider the current development of the automotive market, but also focus on the future development of the international market. The new development concept in our country at present is the requirement of green development, and the implementation of the development strategy of energy saving and emission reduction.Actually, the development of new energy has become one of the major tasks for the development of various industries. Thus, the automobile enterprises should coordinate the development of new energy automotive industry and the national energy policy requirements.

The important challenge of the development of new energy vehicles in China is to realize the strategic goal of automobile independent innovation under the national policy and the international automobile market environment. The construction of the target system will ensure the rapid and effective development of new energy resources.

\section{B. The Policy System of Industrial Innovation}

According to the target system, China's energy conservation policies affect the development of China's new energy automotive industry. The development of the traditional system of the automobile industry has an important effect on the industrial innovation system of new energy vehicles. New energy innovation policy is subject to strict planning, reflecting the development stage of China's automobile industry. Industrial innovation policies include industry supply policy, market demand policy, policy rating, etc., and industrial innovation policy really has certain guiding significance. Enterprises in the formulation of development strategies usually conform to the relevant national policy direction. The automobile enterprise innovation and development and the international automobile technology development level and the automobile market is inseparable, as the enterprises need to develop stage target while long-term policy requirements are linked to 
development through the market mechanism,so as to guide the car enterprises to carry out energysaving technology. In addition, through the guiding role of policy, it actively promotes the industrialization of new energy vehicles, opening up a broad market.

\section{Technological System of Industrial Innovation}

The difference between the new energy vehicles and the traditional cars lies in energy saving technology, and there is a big difference from the traditional automotive technology. The core of the new energy technology innovation system is the energy saving technology of the automobile, and it has been matched with various automobile production technologies to form a technical system with key technology. Among them, the same part of the traditional technology refers to the technology that has been widely used in the automotive field, and has a huge impact on the depth of the entire automotive industry.

The same trends with the new energy automotive industry and traditional automobile industry are the generic technology and other automotive industry technology. While the key technology of new energy refers to promote the competitiveness of new energy automotive industry and influence of the technology.Therefore, the key technology of new energy vehicles will become the core of the automobile industry.

\section{Industrial Innovation Environment and Socialized Service System}

The industry innovation environment not only includes the hardware environment and software environment of new energy automobile industry innovation,but also includes automobile industry structure, social service system and so on.

The socialized service system of the new energy automobile industry is inseparable from the whole society's energy saving consciousness, environmental protection consciousness, market demand and national policy. The basis of environment and social system is the development, production and socialization of new energy vehicles.

It is accompanied by the adjustment of industrial structure, the market environment of automobile and the innovative spirit of automotive $\mathrm{R} \& \mathrm{D}$ personnel. In addition, the social service system is closely related to the construction of innovative networks, and the development of the social service system has an important impact on the development of new energy vehicles.

\section{The innovation system structure and function of new energy vehicles in China}

From the automobile industry innovation process and results, the new energy automotive industry innovation system refers to the development of energy-saving and environmental protection automobile products as the goal, the automobile industry in the construction enterprises as the main innovation, between enterprises and between enterprises and universities, research institutions, users and suppliers, financial institutions, government the cooperation in the network, the effective innovation mechanism and policy guidance, to achieve industrial innovation.

From the United States energy automotive industry innovation action, it can be seen in the development of China's new energy automotive industry, the innovation system should include four parts: (1) the goal of innovation system of industry; (2) industrial innovation policy system; (3) industrial technology innovation system; (4) industrial innovation environment and service system.

Below is the basic framework of environmental-friendly automobile innovation system, which can be taken as a reference.

\section{Conclusion}

The development of new energy automotive products and industrial innovation has gradually been an important part of national innovation, which can promote economic development, economic growth, and improve the overall competitiveness of China's automobile industry. It is of great significance. The construction industry innovation system of new energy vehicles will help us to understand the process of the development of China's automobile industry, including their problems and deficiencies. 
Considering the gap of our country and the developed countries in the development target, policy system, technology system, innovation environment and service system , it is really necessary to change and improve the status of China's automobile industry in the global auto industry in the layout, it is also the basic content of innovative national strategy.

The development target and policy system of new energy automobile industry are related together. Emphasis on the development of new energy vehicles aims to design a complete policy system, so as to give full play to the policy forces.

Stimulate the innovative behavior of the innovation subjects, and further promote the market process of technology products. The innovation environment of automobile industry cannot be without reasonable adjustment of industrial structure, without the provision and improvement of entrepreneurial knowledge and intellectual resources innovation atmosphere, so to strengthen the innovation network construction and perfect service system is essential.

At present, the new energy automotive industry innovation system is an important part of the national automobile industry innovation system.Not only the policy system,but also technology paradigm and industrialization require innovation environment and service system which are the fundamental differences during the research, and require us to strengthen the internal structure and function of system.

From a technical point of view, the system requirements strengthen cooperation and common development of common knowledge and key technologies and joint research in automotive technology development. Considering technology products from social perspective, we seek to strengthen mutual cooperation between different industries in the broader scope.

This is the content of technological innovation activities, which is the difference between technological innovation activities and our past technological innovation and technological progress activities. The establishment of technological innovation system is a necessary condition to ensure the development of technological innovation activities.It will be penetrated into all aspects of the development of the automobile industry, and the automobile industry has been developed in the continuous innovation activities. Therefore, we can wait for the future condition of the new energy industry.

\section{Acknowledgment}

This paper is funded by Project of "Research on electric vehicle braking regenerative power generation”, College level project of Guangdong University of Science \& Technology in 2015(GKY2015KYYB-3).

\section{References}

[1] ic materials [M]. Beijing: Tsinghua University Press .2010.362 - 368

[2] Hou Q J, Lin J, Chen K H. The Study on the Function of New Energy Automobile Innovation System[J]. Economic Management Journal, 2015.

[3] Lei L I, Guo Y, Business S O, et al. The Study on the Innovation Ecosystem Construction of China's New Energy Automotive Industry[J]. Science \& Technology Management Research, 2014.

[4] Zhang J. R\&D for Environmental Innovation and Supportive Policy: The Implications for New Energy Automobile Industry in China[J]. Energy Procedia, 2011, 5:1003-1007.

[5] Deng-Feng H U, Wang L P. Research on Chinese New Energy Automobile Industry Innovation System[J]. Soft Science, 2010.

[6] Liang Xi, Lin Lei, Wu Guisheng. Evolution of the Chinese Automobile Industry from a Sectoral System of Innovation Perspective[J]. Industry \& Innovation, 2009, 16(4-5):463-478.

[7] Wang C X. Research on independent innovation of automobile industry in China[J]. Economic \& Trade Update, 2007. 
[8] Zhang Xiaoyu.Application mechanics of automobile engineering [M]. Vehicle power, 2013, (2): 65-98.

[9] Tan Ying, Zhang Jun. Automobile Internship Guide Driver, 2011, (5): 127-131.

[10] LIU Jian-jun.Effects of Vehicle Braking System [J]. Journal of Xinyu University 2012 (02)

[11] H Holec, Applied mechanics of Automotive Engineering (Oxford: Pergamum Press, 2011), 22.

[12] YANG Fei-qiu.Study on the Influence of Automobile Braking [J]. Journal of Shandong Normal University Foreign Language Institute. 2011 (05)

[13] How to improve the performance of traffic brake [J]. Test Weekly. 2011 (17)

[14] Pang Weiguo.Study on the Improvement of Automobile Braking Performance [J]. Journal of East China Normal University, 2012 (2): 19-21. 